\title{
COMUNICACÕES
}

\section{Occurrence of Target Spot, caused by Corynespora cassiicola, on cotton plants in Dourados, Mato Grosso do Sul State}

\author{
Augusto César Pereira Goulart ${ }^{1}$, Fernando Mendes Lamas ${ }^{1}$
}

${ }^{1}$ Embrapa Agropecuária Oeste - Caixa Postal 661, 79804-970, Dourados, MS

Autor para correspondência: Augusto César Pereira Goulart (augusto.goulart@embrapa.br)

Data de chegada: 23/05/2016. Aceito para publicação em: 06/06/2016.

$10.1590 / 0100-5405 / 2193$

Target spot or Corynespora leaf blight is a traditional soybean disease caused by Corynespora cassiicola (Berk \& Curt.) Wei. This disease was first reported on soybean in Brazil in 1974. The fungus has been found in almost all soybean growing regions in Brazil, causing economic losses. C. cassiicola survives on crop residues and infected seeds, which are the main way of spread. The fungus is capable of infecting a large number of crop plants (Soares, R. M; Godoy, C. V; Oliveira, M. C. N. de. Escala diagramática para avaliação da severidade da mancha alvo da soja. Trop. plant pathol.[online]. 2009, vol.34, n.5). On cotton, this disease was first reported in the state of Mato Grosso, Brazil, in 1995 (Mehta, Y.R., Motomura, K.F. and Almeida, W.P. Corynespora Leaf Spot of Cotton in Brasil. Fitopatologia Brasileira, 30, 131. 2005). In
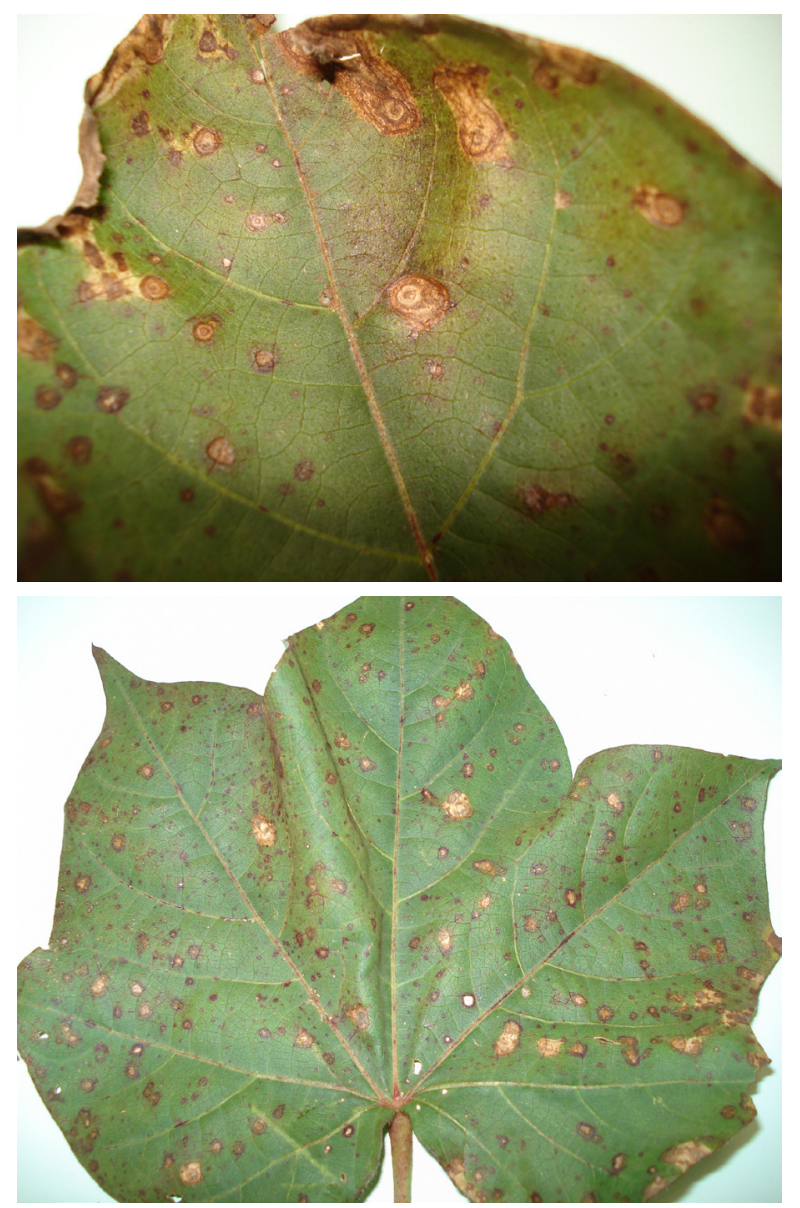

Figure 1. Cotton leaves showing typical symptoms of target spot the Brazilian Amazon, the pathogen of target spot has caused losses in tomato and cucumber plants. In recent years, target spot has been spread across cotton growing areas in Brazil, especially in the state of Mato Grosso, and has emerged as an important disease causing heavy yield losses (Galbieri, R., Araújo, D.C.E.B., Kobayasti, L., Girotto, L., Matos, J.N., Marangoni, M.S., Almeida, W.P. and Mehta, Y.R. (2014) Corynespora Leaf Blight of Cotton in Brazil and Its Management. American Journal of Plant Sciences,

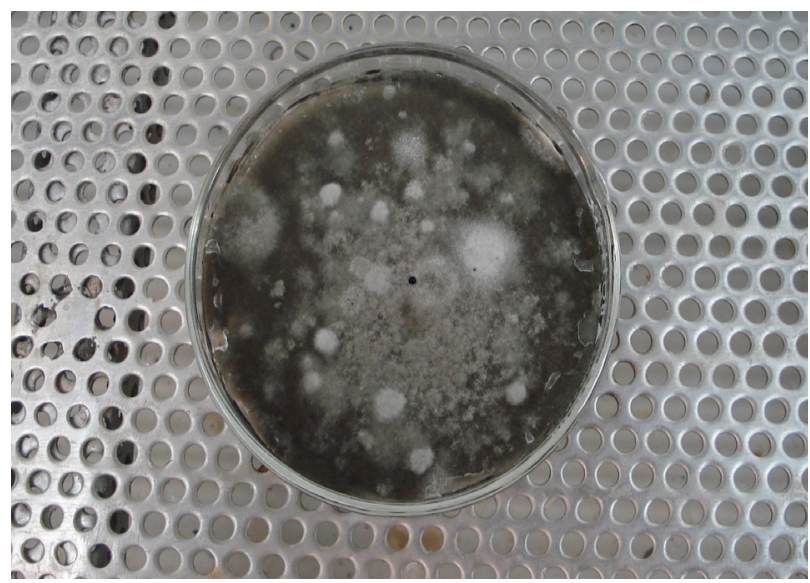

Figure 2. Fungal colony on PDA medium

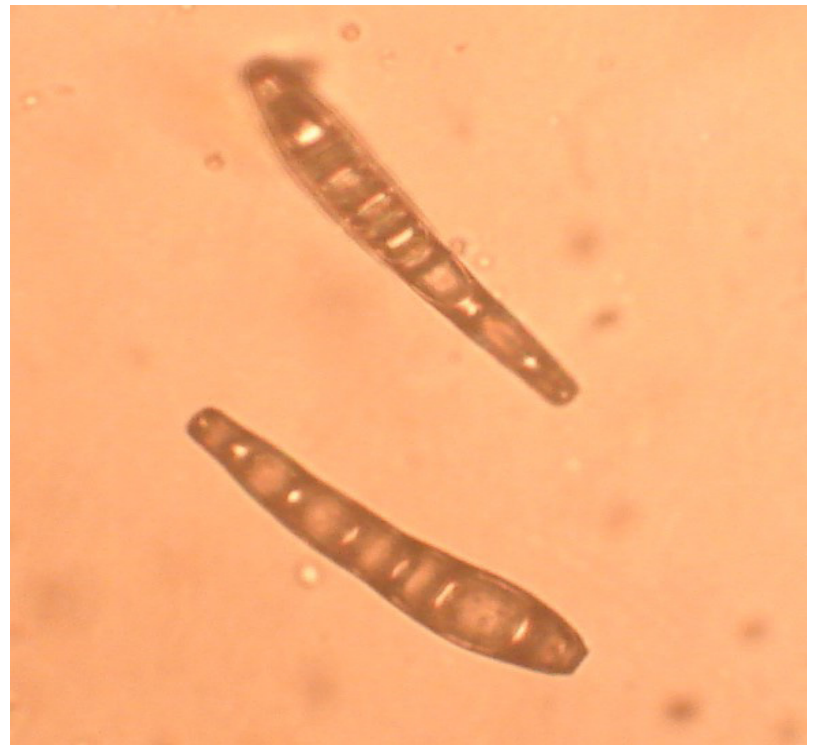

Figure 3. Conidia of Corynespora cassiicola 
5, 3805-3811). In Mato Grosso do Sul State, the first report of this disease on cotton was in the 2011/2012 crop season (http:// ocorreionews.com.br/portal/2015/05/14/historico-diagnose-econtrole-de-mancha-alvo-corynespora-cassiicola-na-cultura-doalgodoeiro-na-regiao-dos-chapadoes/). The symptoms of this disease on cotton plants are similar to those observed on soybean plants. In the foliar phase of the disease, the symptoms first appear on the leaves in the lower canopy and spread upward through the canopy towards the shoot tips, characterized as small circular spots. The well developed lesions are necrotic and show typical "target spot" (concentric rings) symptoms, with alternating light and dark brown bands and depression at the center of the lesion. Once multiple leaf spots appear, diseased leaves senesce, showing severe necrosis, and fall to the ground. In 2015, at the experimental field of Embrapa Western Agriculture, in Dourados, MS, cotton plants of the cultivars BRS 369 RF, FMT 709 and FM 975 WS showing typical symptoms of target spot were observed. Infected leaves were collected and taken to the laboratory for analysis. Isolation of the pathogen from leaves showing typical symptoms of target spot was done by disinfecting small leaf fragments with $70 \%$ alcohol and $2 \%$ sodium hypochlorite, followed by transference to Petri dishes containing PDA culture medium. Ten days after incubation at $22^{\circ} \mathrm{C}$, fungal colonies were observed. Based on these characteristics and morphological features, the pathogen was identified as Corynespora cassiicola. Pathogenicity tests were carried out under greenhouse conditions by inoculating the fungus in healthy ten-day-old cotton plants $\left(4 \times 10^{4}\right.$ conidia/ml). Eight days after inoculation, symptoms similar to those observed on cotton plants in the field were evident in the inoculated plants. The pathogen was reisolated from lesions observed in the inoculated plants and the recovered colonies were similar to the inoculated colony. This pathogen was characterized as Corynespora cassiicola, concluding Koch's postulates. 